\title{
ANALISA KEBUTUHAN PENGEMBANGAN MEDIA PEMBELAJARAN PADA MATA PELAJARAN KONSTRUKSI DAN UTILITAS GEDUNG DI KELAS DESAIN PERMODELAN DAN INFORMASI BANGUNAN SMK NEGERI 1 PERCUT SEI TUAN
}

\author{
Sri Ana Tambunan \\ Pendidikan Teknik Bangunan, FT, UNIMED \\ Email: srianaulinda17@gmail.com
}

\begin{abstract}
ABSTRAK
Penelitian ini bertujuan untuk menganalisa kebutuhan peserta didik terhadap pengembangan media pembelajaran pada mata pelajaran Kontruksi dan Untilitas Gedung di Kelas Desain Permodelan dan Informasi Bangunan di SMK Negeri 1 Percut Sei Tuan. Analisa kebutuhan dilakukan berdasarkan tahapan pertama dari model Lee and Owens yaitu penilaian atau analisis. Hasil dari penelitian ini adalah analisa kebutuhan yang tujuan utamanya untuk mengidentifikasi kesenjangan antara kondisi aktual dan kondisi yang seharusnya. Pengumpulan data pada penelitian ini menggunakan kuesioner dengan jenis data kualitatif. Kuesioner tersebut disebar menggunakan google form sehingga responden dapat mengisi kuesioner tersebut secara online. Berdasarkan hasil analisa kebutuhan yang telah dilakukan, terdapat beberapa masalah pada media pembelajaran yang digunakan: (1) media pembelajaran yang digunakan biasa saja sehingga kurang memotivasi belajar, (2) materi pembelajaran termasuk materi yang sulit, namun pemahaman terhadap materi biasa aja, dan (3) materi pembelajaran yang digunakan masih berupa media presentasi.
\end{abstract}

Kata kunci: Analisa Kebutuhan, Media Pembelajaran, Konstruksi dan Utilitas Gedung

\section{ABSTRACT}

This study aims to analyze the needs of students for the development of learning media in the subjects of Construction and Building Utilization in the Modeling Design and Building Information Class at SMK Negeri 1 Percut Sei Tuan. Needs analysis is carried out based on the first stage of the Lee and Owens model, namely assessment or analysis. The result of this research is a needs analysis whose main purpose is to identify the gap between the actual condition and the condition that should be. Data collection in this study used a questionnaire with qualitative data types. The questionnaire was distributed using a google form so that respondents could fill out the questionnaire online. Based on the results of the needs analysis that has been carried out, there are several problems with the learning media used: (1) the learning media used are ordinary so they do not motivate learning, (2) the learning materials include difficult material, but understanding of the material is ordinary, and 3) the learning materials used are still in the form of presentation media.

Keywords: Needs Analysis, Learning Media, Construction and Building Utilities

\section{PENDAHULUAN}

Perkembangan teknologi informasi yang pesat memberikan dampak berupa gaya hidup digital, yang menyebabkan seseorang hidup berdampingan dan tidak dapat dipisahkan oleh teknologi informasi (Trilling \& Fadel, 2009). Gaya hidup digital ini juga memberikan dampak kepada peserta didik, yaitu peserta didik saat ini lebih tertarik dan terbiasa dengan penggunaan teknologi informasi untuk keperluan sosial maupun akademis (Shahroom \& Hussin, 2018; Yoon et al., 2013). Dampak ini menyebabkan peserta didik menuntut lingkungannya untuk didukung dengan ketersediaan teknologi informasi setiap saat (Mcmahon \& Pospisil, 2005). Namun, penggunaan teknologi informasi untuk keperluan akademis masih rendah dibandingkan keperluan sosial (Gayatri et al., 2015; Sim \& Butson, 2013). 
Untuk menyediakan pembelajaran yang sesuai dengan tuntutan perkembangan teknologi informasi, salah satunya dapat dilakukan dengan mengembangkan media pembelajaran pada mata pelajaran konstruksi dan untilitas gedung. Konstruksi dan Untilitas gedung merupakan mata pelajaran dasar pada program studi Pendidikan Teknik Bangunan, yang membahas tentang keselamatan, keamanan, dan kerja dan lingkungan. Untuk memahami materi pada Kontruksi dan Untilitas Gedung, diperlukan kemampuan analisa teori yang didukung dengan pengamatan langsung di laboratorium (Gere \& Timoshenko, 2013). Pengembangan media pembelajaran pada mata kuliah Kontruksi dan Untilitas Gedung, dapat memaksimalkan penggunaan model pembelajaran (Hastuti et al., 2018) dan dapat menggantikan peran laboratorium konvensional (Arista \& Kuswanto, 2017), sehingga diharapkan dapat meningkatkan nilai rata-rata dan mengurangi jumlah peserta didik yang tidak lulus.

Pengembangan suatu media pembelajaran dilakukan dalam beberapa tahapan, sesuai dengan model desain instruksional yang digunakan. Secara umum, tahapan pertama dalam mengembangkan media pembelajaran adalah melakukan analisa kebutuhan (Kusuma Negara et al., 2019; Syahron et al., 2017; Tampubolon et al., 2017). Analisa kebutuhan merupakan proses sistematis untuk menentukan tujuan, mengidentifikasi kondisi aktual dan yang diharapkan, serta menetapkan prioritas tindakan (Lee \& Owens, 2004). Analisa kebutuhan dalam mengembangkan media pembelajaran dilakukan untuk mengetahui penilaian peserta didik terhadap media pembelajaran yang digunakan serta harapan terhadap media pembelajaran yang akan dibuat.
Penelitian ini bertujuan untuk menganalisa kebutuhan untuk pengembangan media pembelajaranpada mata pelajaran Kontruksi dan Untilitas Gedung, untuk program studi Pendidikan Teknik Bangunan. Analisa kebutuhan dilakukan berdasarkan tahapan pertama dari model Lee \& Owens (2004) yaitu assessment/analysis.

Media pembelajaran merupakan alat yang digunakan untuk menyampaikan pesan dan informasi selama pembelajaran. Lebih spesifik, menurut Rachman (2016) media pembelajaran adalah alat yang digunakan untuk menjelaskan fakta, konsep, prinsip, maupun prosedur yang ditujukan untuk menyediakan pengalaman yang lebih nyata sehingga dapat memotivasi dan meningkatkan pemahaman serta daya ingat peserta didik selamapembelajaran.Selain itu, media pembelajaran dapat memfasilitasi proses pembelajaran peserta didik yang memiliki gaya belajar yang berbeda-beda (Smaldino et al., 2008).

Sejalan dengan perkembangan teknologi informasi, media pembelajaran juga mengalami perkembangan terutama multimedia. Hal ini dikarenakan multimedia dapat diterapkan ke dalam bentuk internet, presentasi, tutorial, referensi, dan publikasi (Bakri, 2010). Karena multimedia dapat diterapkan dalam berbagai bentuk sesuai dengan perkembangan teknologi, maka pemanfaatan teknologi multimedia menjadi media pembelajaran sama dengan memanfaatkan perkembangan teknologi yang ada untuk dijadikan media pembelajaran.

Dalam mengembangkan suatu media pembelajaran, diperlukan sebuah prosedur pengembangan yang disebut dengan desain instruksional. Menurut Seel et al. (2017), desain instruksional merupakan sebuah prosedur yang sistematis untuk 
mengembangkan dan menyusun program pendidikan sehingga memiliki tujuan untuk meningkatkan pembelajaran yang substansial. Ada banyak model desain instruksional yang dapat digunakan untuk mengembangkan media pembelajaran. Namun pada umumnya, tahapan pertama untuk mengembangkan media pembelajaran adalah melakukan analisa kebutuhan.

Menurut Songhori (2008), istilah analisa kebutuhan secara umum merujuk ke aktivitas yang melibatkan pengumpulan informasi untuk mengidentifikasi kebutuhan dari sekelompok peserta didik. Dengan dilakukannya analisa kebutuhan dalam mengembangkan media pembelajaran, perancang akan lebih memahami kesenjangan yang ada antara hasil akhir yang diinginkan dengan pengetahuan dan keterampilan yang telah dimiliki oleh sekelompok peserta didik (Rachman, 2016). Sehingga media pembelajaran yang akan dibuat lebih sesuai dengan kebutuhan yang ada berdasarkan permasalahan yang teridentifikasi melalui analisa kebutuhan.

\section{METODE}

Penelitian ini akan dilaksanakan di Kelas Desain Permodelan Dan Informasi Bangunan SMK Negeri 1 Percut Sei Tuan pada tahun ajaran 2019/2020. Populasi dalam penelitian ini adalah seluruh peserta didik Kelas Desain Permodelan Dan Informasi Bangunan SMK Negeri 1 Percut Sei Tuan Kelas XI 2. Pengumpulan data pada penelitian ini menggunakan kuesioner dengan jenis data kualitatif dan disebar menggunakan google form sehingga responden dapat mengisi kuesioner tersebut secara online. Periode pengisian kuesioner adalah tanggal 16 - 17 November 2020 .
Skala pengukuran yang digunakan pada kuesioner tersebut dibagi menjadi dua jenis. Untuk pertanyaan yang jawabannya berupa pendapat responden, skala yang digunakan adalah skala nominal. Sedangkan untuk pertanyaan yang jawabannya berupa penilaian responden, skala yang digunakan adalah skala Likert. Untuk data dengan skala nominal, data dihitung berdasarkan banyaknya jumlah responden pada masingmasing pilihan jawaban pada kuesioner. Untuk data dengan skala Likert, data dihitung dengan menggunakan rumus berikut:

\section{skor $=($ item jawaban $\times$ jumlah responden $)$}

Kemudian, skor yang telah dihitung dibandingkan dengan skoritem dikalikan dengan total responden untuk masingmasing item.

\section{HASIL DAN PEMBAHASAN}

Berikut ini adalah hasil analisa kebutuhan yang didapatkan melalui pengisian kuesioner melalui google form pada tanggal 16 - 17 November 2020 dengan total jumlah responden adalah 80 . Indikator identitas responden ditanyakan di bagian awal analisa kebutuhan untuk mengetahui identitas responden secara singkat. Pada indikator ini terdapat tiga pertanyaan, yaitu nama responden, jenis kelamin, dan angkatan.

Pertanyaan mengenai jenis kelamin pada analisa kebutuhan ditujukan untuk mengetahui jenis kelamin dari masingmasing responden. 


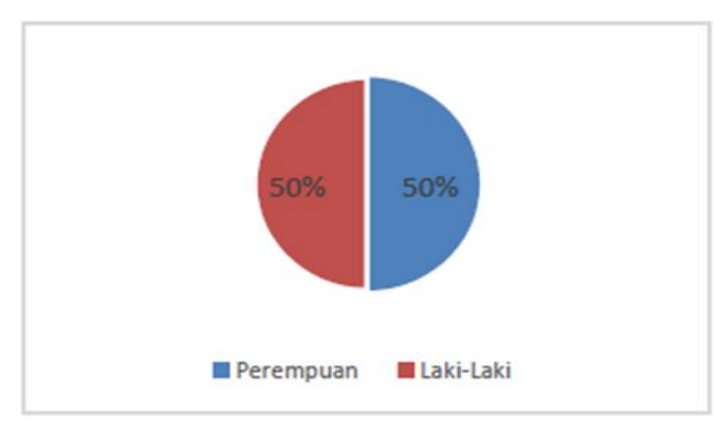

Gambar 1. Analisa Jenis Kelamin

Berdasarkan hasil analisa tersebut, didapatkan bahwa $50 \%$ responden berjenis kelamin perempuan, sedangkan 50\% lainnya berjenis kelamin laki-laki.

Pertanyaan mengenai angkatan pada analisa kebutuhan ditujukan untuk mengetahui angkatan dari masing-masing responden.

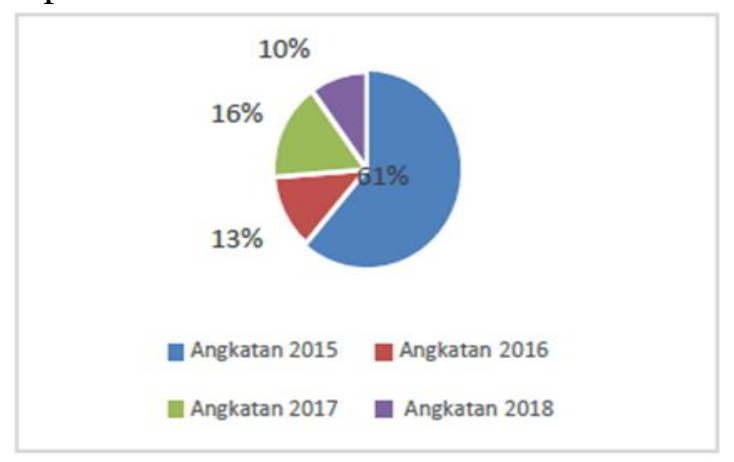

Gambar 2. Analisa Angkatan

Berdasarkan hasil analisa tersebut, didapatkan bahwa $61 \%$ dari angkatan 2015, $16 \%$ dari angkatan 2017, 13\% dari angkatan 2016, dan 10\% dari angkatan 2018.

Indikator pembelajaran Mekanika Bahan di kelas ditujukan untuk mendapatkan gambaran mengenai metode apa yang digunakan oleh pendidik dan tanggapan peserta didik terhadap pembelajaran tersebut. Pada indikator ini terdapat tiga pertanyaan, yaitu metode pembelajaran, pemahaman akan materi, dan tingkat kesulitan materi.

Pertanyaan mengenai metode pembelajaran ditujukan untuk mengetahui metode pembelajaran yang paling sering digunakan pendidik selama pembelajaran.

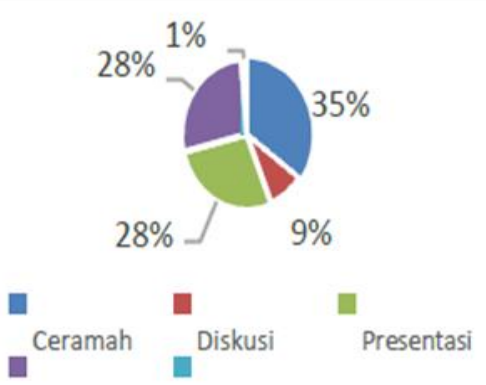

Gambar 3. Analisa Metode Pembelajaran

Berdasarkan analisa tersebut, didapatkan bahwa metode ceramah adalah metode yang paling sering digunakan dengan persentase sebesar $35 \%$.

Tabel 1. Penilaian Pembelajaran di Kelas

\begin{tabular}{clll}
\hline No & Pertanyaan & Skor & Ket \\
\hline 1 & $\begin{array}{l}\text { Pemahaman } \\
\text { terhadap materi } \\
\text { yang } \\
\text { disampaikan }\end{array}$ & 221 & $\begin{array}{l}\text { Biasa } \\
\text { saja }\end{array}$ \\
\hline 2 & $\begin{array}{l}\text { Tingkat kesulitan } \\
\text { materi } \\
\text { pembelajaran }\end{array}$ & 297 & Sulit \\
\hline
\end{tabular}

Berdasarkan penilaian responden terhadap pembelajaran di kelas, dapat disimpulkan bahwa pemahaman peserta didik terhadap materi yang disampaikan adalah biasa saja dengan tingkat kesulitan materi pembelajaran pada mata kuliah Mekanika Bahan adalah sulit.

\section{SIMPULAN}

Hasil dari penelitian ini adalah analisa kebutuhan yang berguna untuk menentukan tujuan, mengidentifikasi kesenjangan antara kondisi aktual dan kondisi seharusnya, serta menentukan prioritas. Berdasarkan hasil analisa kebutuhan yang telah dilakukan, dapat diidentifikasi beberapa permasalahan pada media pembelajaran Mekanika Bahan, 
diantaranya (1) Peserta didik memerlukan media pembelajaran yang menarik untuk menunjang pembelajaran Mekanika Bahan.

Namun, media pembelajaran yang digunakan biasa saja sehingga kurang memotivasi peserta didik untuk belajar. (2) Materi pembelajaran Mekanika Bahan termasuk materi yang sulit. Namun, pemahaman peserta didik terhadap materi pada materi biasa saja, sehingga diperlukan.

\section{DAFTAR RUJUKAN}

Arista, F. S., \& Kuswanto, H. (2017). Virtual Physics Laboratory Application Based on the Android Smartphone to Improve Learning Independence andConceptual Understanding. International Journal of Instruction, 11 (1), 1-16.

Bakri, H. (2010). Langkah-langkah pengembangan pembelajaran multimedia interaktif. Jurnal Medtek, 2 (1), 1-8.

Gayatri, G., Rusadi, U., Meiningsih, S., Mahmudah, D., Sari, D., \& Nugroho, A. C. (2015). Perlindungan Pengguna Media Digital Di Kalangan Anak Dan Remaja Di Indonesia. Jurnal Penelitian Dan Pengembangan Komunikasi Dan Informatika, 6(1), 1-18.

Kusuma Negara, R. I. T., Iriani, T., \& Lenggogeni. (2019). Pengembangan Multimedia Interaktif pada Mata Kuliah Manajemen Konstruksi di S1 Pendidikan Teknik Bangunan Universitas Negeri Jakarta. Jurnal Pendidikan Teknik Sipil, 8(2), 97104.
Lee, W. W., \& Owens, D. L. (2004). Multimedia- Based Instructional Design (2nd ed.). San Francisco: Pfeiffer.

Mcmahon, M., \& Pospisil, R. (2005). Laptops for a digital lifestyle: Millennial students and wireless mobile technologies. ASCILITE 2005 - The Australasian Society for Computers in Learning in Tertiary Education, (2001), 421-431.

Sumardjo, S., Pratama, G. N. I. P., \& Vemantyasto, T. N. (2020). Efektivitas Modul Estimasi Biaya Konstruksi Jalan pada Mata Pelajaran Estimasi Biaya Konstruksi Di SMK N 1 Purworejo. Jurnal Pendidikan Teknik Sipil,2(2), 104116.

Titania, T., \& Widodo, S. (2020). Pengembangan Media Pembelajaran Video Animasi untuk Mata Pelajaran Mekanika Teknik Kelas X Desain Pemodelan dan Informasi Bangunan di SMK N 2 Yogyakarta. Jurnal Pendidikan Teknik Sipil, 2(2), 89-94. 